\title{
Географические и климатические особенности Центральнокамчатской низменности. История и перспективы наблюдательной астрономии на полуострове Камчатка
}

\author{
А.Л. Рьбак \\ Главная (Пулковская) астрономическая обсерватория РАН, Пулковское шоссе, 65, Санкт-Петербург \\ solarfish@alexeyryback.ru
}

Поступила в редакцию 2 ноября 2017 г.

Аннотация. В данной работе рассмотрены особенности Центральнокамчатской низменности. Обсуждаются возможные перспективы организации регулярных астрономических наблюдений на полуострове.

THE CENTRAL VALLEY OF KAMCHATKA: GEOGRAPHICAL AND CLIMATICAL FEATURES. HISTORY AND PERSPECTIVES OF OBSERVATIONAL ASTRONOMY IN KAMCHATKA, by A.L. Rybak. The features of the Central Valley of Kamchatka are described in the work. Perspectives of regular astronomical observations are discussed.

Ключевые слова: Центральнокамчатская низменность, астроклимат, наблюдательная астрономия

\section{1 Камчатка на земном глобусе}

Чукотка и полуостров Камчатка находятся на северо-восточной оконечности Евразии и в меридиональном измерении вдаются вглубь Тихого океана. Если “пройтись” по земному шару вдоль камчатского меридиана, окажется, что “ближайшими” соседями будут Соломоновы острова в экваториальной части Тихого океана. В наблюдательной астрономии можно найти задачи, требующие непрерывного мониторинга, например, обнаружение и регистрация гамма-всплесков. При этом желательно, чтобы небесный объект находился на максимальной высоте над горизонтом с целью получения качественного сигнала. Даже в эпоху космических обсерваторий ценность наземных наблюдений никто не ставит под сомнение. В этом смысле идея наблюдательной астрономии на полуострове Камчатка имеет вполне конкретное значение.

\section{2 Климат Камчатского края}

Для климата Камчатки характерно чрезвычайное разнообразие и неустойчивость погоды, обусловленные географическим положением, влиянием окружающих морей и Тихого океана, движением воздушных масс, рельефом. Побережье полуострова имеет черты морского климата. В центральных и северных районах климат близок к континентальному. 
Самой холодной частью полуострова зимой является Центральнокамчатская низменность, где средняя температура января $-22{ }^{\circ} \mathrm{C}$. “Полюс холода” находится в пос. Верхнее Пенжино, где зарегистрирована температура $-64^{\circ} \mathrm{C}$. На всей территории области в течение зимы наблюдаются оттепели, нередки случаи повышения температуры до $+5{ }^{\circ} \mathrm{C}$ в январе и феврале.

Наиболее высокие температуры на побережье и островах наблюдаются в августе, в центральной части полуострова зарегистрированы в июле. Наибольшее значение - в районе с. Долиновка $\left(+37^{\circ} \mathrm{C}\right.$.). Число теплых дней с температурой выше $20^{\circ} \mathrm{C}$ на Камчатке невелико. На побережье за все лето их наблюдается от 1 до 6, в материковой части - до 20-30, а в долине р. Камчатка - от 35 до 55.

В Центральнокамчатской низменности, защищенной от влияния циклонов мощными хребтами, зимой преобладает морозная, сравнительно тихая, малооблачная погода континентального типа.

В пределах Камчатской области осадков выпадает больше, чем в любой другой области страны, и по сезонам неравномерно. Наибольшее количество осадков - до 2500 мм в год - выпадает на восточных и наветренных склонах гор юга полуострова. В Центральнокамчатской низменности, защищенной от влияния циклонов Срединным и Восточным хребтами, оно составляет в среднем 400 мм в год (Кириллов, 1994).

В камчатский астроклимат определенные коррективы вносит вулканическая деятельность на полуострове. Большинство вулканов концентрируются к восточному побережью Камчатки. K тому же многие из действующих вулканов извергаются непостоянно.

\section{3 История и перспективы наблюдательной астрономии на Камчатке}

В середине 2007 года на Камчатку была организована совместная экспедиция ГАО РАН и УАФО ДВО PAН, целью которой было проведение пробных наблюдений геостационарной орбиты на территории ИКИР РАН в селе Паратунка при помощи телескопа MEADE LXD75. Тестовые наблюдения оказались успешными, однако запустить регулярный обзор неба не удалось ввиду сложных климатических условий в окрестностях тихоокеанского побережья Камчатского полуострова.

Полгода спустя наблюдения на Камчатке были возобновлены. Наблюдательная площадка была выбрана в 20 км от села Мильково, которое расположено в центре полуострова. Центральнокамчатская низменность обрамлена Срединным и Восточным хребтами, защищающими ее от ветров и влажных воздушных масс. Ввиду этого климат на территории низменности похож на сухой резко континентальный климат внутренних районов Восточной Сибири.

Основной проблемой, которая препятствовала успешным наблюдениям зимой 2008 года, являлась непрочная монтировка телескопа MEADE LXD75. Пластмассовые детали монтировки не выдерживали на морозе постоянных поворотов трубы двадцатисантиметрового телескопа. В марте в Мильково была доставлена монтировка EQ6 Pro, которая была установлена на зацементированную колонну, а на саму монтировку была подвешена труба от телескопа MEADE LXD75. Результаты этих манипуляций не заставили себя ждать: в ночь на 5 апреля было проведено около одной тысячи измерений по космических объектам в пятидесяти проводках.

По итогам всего 2008 года было получено около шестнадцати тысяч измерений в девятистах проводках.

Успешный опыт астрономических наблюдений на Камчатском полуострове усилиями малых телескопов выносит на повестку дня новые задачи. Астроклиматические особенности данного региона нашей страны связаны не столько с географическим положением, сколько с пересеченным рельефом самой Камчатки. Наличие хорошо изолированной от влажных воздушных масс и резким континентальным климатом Центральнокамчатской низменности указывает на необходимость наращивания наблюдательной группировки на этой территории. Небольшие телескопы можно было бы разместить с севера на юг как в самой долине, так и на невысоких сопках, расположенных на территории низменности.

\section{Литература}

Кириллов В.И. // Камчатка: справочник туриста. Петропавловск-Камчатский: РИО КОТ. 1994. 